\title{
腎盂尿管腫瘍46例の治療成績
}

\begin{tabular}{|c|c|c|c|c|c|}
\hline 佳郎* & 牛山 & 知己 & 田島 & 惇 & 鈴木 \\
\hline 大田原佳久 & 太田 & 信隆 & 大見 & 嘉郎 & 畑 \\
\hline 増田 宏昭 & 神林 & 知幸 & 鈴木 & 俊秀 & 北川 \\
\hline 正男 & 鈴木 & 明彦 & 塚田 & 隆 & 中野 \\
\hline
\end{tabular}

\section{TREATMENT OF 46 CASES WITH RENAL PELVIC AND URETERAL TUMORS}

\author{
Yoshio Aso, Tomomi Ushiyama, Atsushi Tajima, Kazuo Suzuki, Yoshihisa Ohtawara, \\ Nobutaka Ohta, Yoshio Ohmi, Masahiro Hata, Hiroaki Masuda, \\ Tomoyuki Kanbayashi, Toshihide Suzuki, Motoaki Kitagawa, \\ Masao Nakahara, Akihiko Suzuki, Takashi Tsukada \\ and Masaru Nakano \\ Department of Urology, Hamamatsu University School of Medicine \\ (Chairman at the time of the present study: Prof. Y. Aso)
}

During about 10 years from November, 1977 to March, 1987, 46 patients with renal pelvic and ureteral tumors were treated at the Department of Urology, Hamamatsu University School of Medicine and the affiliated hospitals.

There were 34 males and 12 females with the highest age incidence in the seventies. Histologically, 44 transitional cell carcinomas and 2 squamous cell carcinomas were found. Of the 44 transitional cell carcinomas, 1 was Tis; $13 \mathrm{~T} 1,2 \mathrm{~T} 2,8 \mathrm{~T} 3,15 \mathrm{M}+$ (with metastatic lesion), and $5 \mathrm{TX}$. As to grading, 1 was G1; 24 G2, 15 G3, and 4 GX. Staging was correlated with grading.

The 5-year survival rates (Kaplan-Meier's method) were $37 \%$ in patients with transitional cell carcinoma. Among patients with transitional cell carcinoma, the 5-year survival rate was $43 \%$ for G2 and $42 \%$ for G3. As to staging, the 5 -year survival rates were $71 \%$ and $46 \%$ in patients with stage of T1 and T3, respectively. No patient with $\mathrm{M}+$ survived longer than 4 years. The 5 -year survival rates were $38 \%$ and $34 \%$ in renal pelvic tumors (24 cases) and ureteral tumors (20 cases), respectively. As to the treatments, the 5-year survival rates after curable treatment (24 cases) and non-curable treatment (20 cases) were $63 \%$ and $7 \%$, respectively.

要旨：1977年11月に浜松医大泌尿器科が開設されて以来1987年 3 月までの約 10 年間に浜松医大泌尿器科 およびその関連病院で治療した腎盂尿管腫場患者は46例であった。

腎孟尿管腫場46例の性別頻度は, 男34例, 女12例と, 約 $3 ： 1$ で男飞多くみられた。年龄別では, 70 歳代が17例と最も多くみられ，次に50歳代，60歳代の順であった。組織型別では，移行上皮癌 44 例 (95.7\%), 扁平上皮癌 2 例 (4.3\%) であった。深達度別では, Tis 1 例, T1 13例, T2 2 例, T3 8 例, 転移あり（M+）15例であった。異型度別では，G1 1例，G2 24例，G3 15例であった。移行上皮癌全 体の 5 年生存率は $37 \%$ だっ。異型度別の 5 年生存率は G2 $43 \%$, G3 $42 \%$, 深達度別では, T $171 \%$, $\mathrm{T} 346 \%, \mathrm{M}+飞 は 5$ 年経過したものは久られなかった。異型度別には有意差はなかったが, 深達度別で $\mathrm{T} 1$ と $+(\mathrm{p}<0.001), \mathrm{T} 3$ と $\mathrm{M}+(\mathrm{p}<0.05)$ の間に有意差を認めた。部位別の 5 年生存率は, 腎盂腫 瘍（ $\mathrm{n}=24 ） 38 \%$ ，尿管腫湟（n=20）34\% と両群間に有意差はなかった。根治的治療のできた群 $(\mathrm{n}=24)$ とできなかった群 $(\mathrm{n}=20)$ についてみると，5年生存率はそれぞれ $63 \% ， 7 \%$ でった。

* 現東京大学泌尿器科 


\section{緒言}

腎血尿管腫瘍は尿路性器腫瘍のなかで予後不良な腫 瘍の一つである。浜松医大泌尿器科開設以来 10 年間に 治療した腎垂尿管腫瘍の治療成績をまとめたので報告 する。

\section{対象および方法}

昭和 52 年 11 月より昭和 62 年 3 月までに浜松医大泌尿 器科およびその関連病院で治療した腎孟尿管腫瘍患者 46例を対象にした。腎昷尿管腫瘍と膀脱腫瘍の合併例 も腎孟尿管腫瘍に含めた。隣接臓器よりの続発性腫瘍, 非上皮性腫瘍は除外した。検討方法は，年齢別・性別 頻度, 組織型別 - 異型度別 - 深達度別の頻度, 組織型 別 - 異型度別 - 深達度別 - 治療法別の生存率について まとめた。異型度は膀脱癌取り扱い規約 ${ }^{1)}$ 準じ, 深達 度は赤座らの分類 ${ }^{2}$ を用い，上皮内癌を Tis，浸潤のな いものを $\mathrm{Ta}$ ，粘膜下に浸潤しているものを $\mathrm{T} 1$ ，筋層 に浸潤しているものを $\mathrm{T} 2$, 尿管, 腎皿の周囲脂肪織ま たは腎実質に浸潤しているものをT3，腎・腎血・尿管 外の周囲藏器に浸潤しているものを $\mathrm{T} 4$, 判定不能の 場合を TX とした。また，リンパ節転移あるいは遠隔

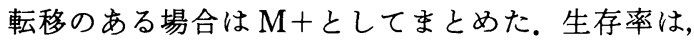
Kaplan-Meier 法により求め ${ }^{3)}$, Log-Rank testにより 検定を扎こなっ。

\section{結果}

1. 性別年齢別頻度（図 1 ）

性別では男34人，女12人と約 $3 ： 1$ で男に多くみら れた，年齢別では70歳代，50歳代，60歳代の順であっ た. 男女とも70歳代にピークがみられたが，50歳代， 60歳代，70歳代で大きな変化はなかった。

図 1 腎昷尿管腫瘍性別年齢別頻度

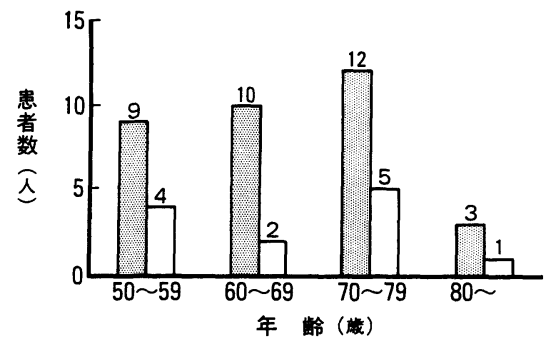

表 1 腎昷尿管腫瘍組織型別頻度

\begin{tabular}{cr}
\hline 移行上皮癌 & $44(95.7 \%)$ \\
扁平上皮癌 & $2(4.3 \%)$ \\
\hline 計 & $46(100 \%)$
\end{tabular}

表 2 腎孟尿管腫瘍異型度，深達度別頻度

\begin{tabular}{|c|c|c|c|c|c|c|c|}
\hline \multicolumn{2}{|c|}{ stage } & G0 & G1 & G2 & G3 & GX & total \\
\hline $\mathrm{M}-$ & $\begin{array}{l}\text { Tis } \\
\mathrm{T} 1 \\
\mathrm{~T} 2 \\
\mathrm{~T} 3 \\
\mathrm{~T} 4\end{array}$ & & 1 & $\begin{array}{r}11 \\
1 \\
4\end{array}$ & $\begin{array}{l}1 \\
1 \\
1 \\
4\end{array}$ & & $\begin{array}{r}1 \\
13 \\
2 \\
8 \\
0\end{array}$ \\
\hline $\mathrm{M}+$ & $\begin{array}{l}\mathrm{T} 1 \\
\mathrm{~T} 2 \\
\mathrm{~T} 3 \\
\mathrm{~T} 4\end{array}$ & & & $\begin{array}{l}1 \\
1 \\
2 \\
2\end{array}$ & $\begin{array}{l}1 \\
2 \\
5\end{array}$ & 1 & $\begin{array}{l}2 \\
1 \\
4 \\
8\end{array}$ \\
\hline \multicolumn{2}{|c|}{$\mathrm{MX}, \mathrm{TX}$} & & & 2 & & 3 & 5 \\
\hline \multicolumn{2}{|c|}{ total } & 0 & 1 & 24 & 14 & 4 & 44 \\
\hline
\end{tabular}

図 2 腎皿尿管腫瘍組織型別生存率

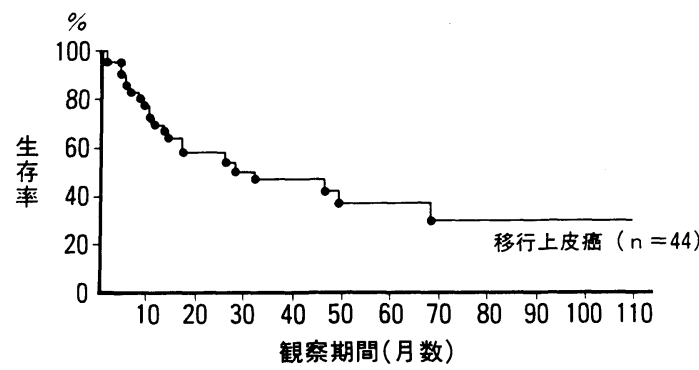

2. 組織型別頻度（表 1 ）

移行上皮癌44例 (95.7\%), 扁平上皮癌 2 例 (4.3\%) と移行上皮癌が大半を占めた。

3. 深達度別・異型度別頻度（表 2)

移行上皮癌 44 例の深達度, 異型度をみると, 深達度 別では, Tis 1 例, T1 13例, T2 2 例, T3 8 例, M+ 15例, TX 5 例であった. T3以上の浸潤性の腫瘍は T2 以下の腫瘍の約 1.5 倍で, その $2 / 3 か ゙$ 転移を有していた。 異型度別では，G1 1 例，G2 24例，G3 15例, GX 4 例であった．1例を除いて G2以上であった，深達度と 異型度との間に相関を認めた $(\mathrm{p}<0.01)$.

4. 生存率

a. 組織型別

移行上皮癌44例について生存率をみると，3 年生存 率 $47 \%, 5$ 年生存率 $37 \%$ であった(図 2 )。扁平上皮癌 2 例はいずれも 1 年以内に死亡した。

b. 異型度別（図 3 ）

移行上皮癌44例のらち異型度の明らかな40例につい て異型度別に生存率をみると, G1は 1 例で 1 年経過し 
図 3 腎血尿管腫瘍異型度別生存率

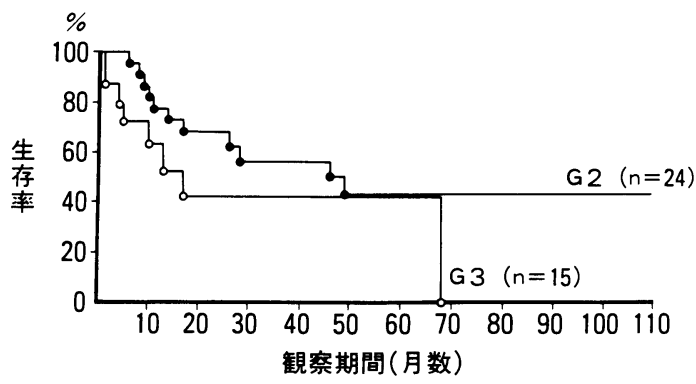

図 4 腎孟尿管腫瘍深達度別生存率

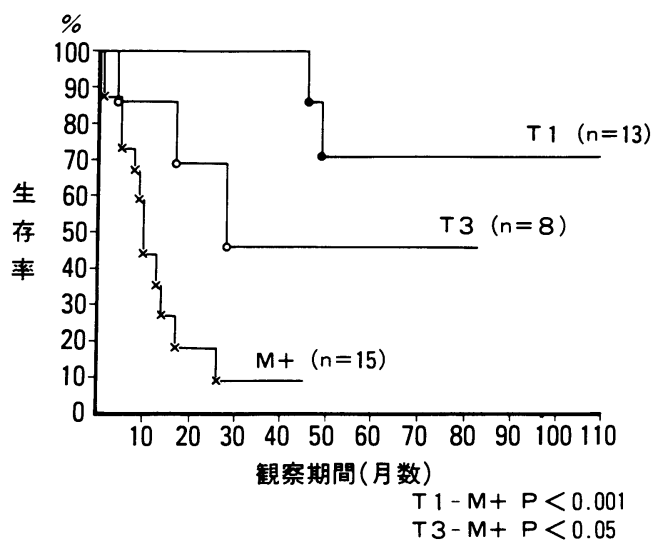

生存中である. $\mathrm{G} 2(\mathrm{n}=24)$ の 3 年生存率は $56 \%, 5$ 年 生存率 $43 \%, \mathrm{G} 3(\mathrm{n}=15)$ の 3 年生存率は $42 \%, 5$ 年生 存率 $42 \%$ あっった。 G2 と 3 の間には有意差はみられ なかった。

\section{c. 深達度別（図 4 ）}

移行上皮癌 44 例のうちで深達度の明らかな39例につ いて深達度別に生存率を検討した. Tis は 1 例で 5 年 8 力月で癌死し, T2 2 例はそれぞれ 3 年11力月, 3 年 7 力月経過し共に生存中である. $\mathrm{T} 1(\mathrm{n}=13)$ の 3 年生
図 5 腎孟尿管腫瘍治療法別生存率

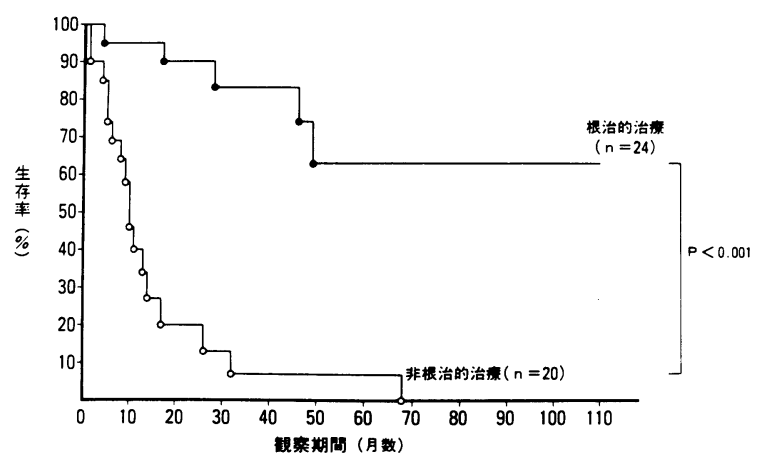

図 6 腎孟尿管腫瘍発生部位別生存率

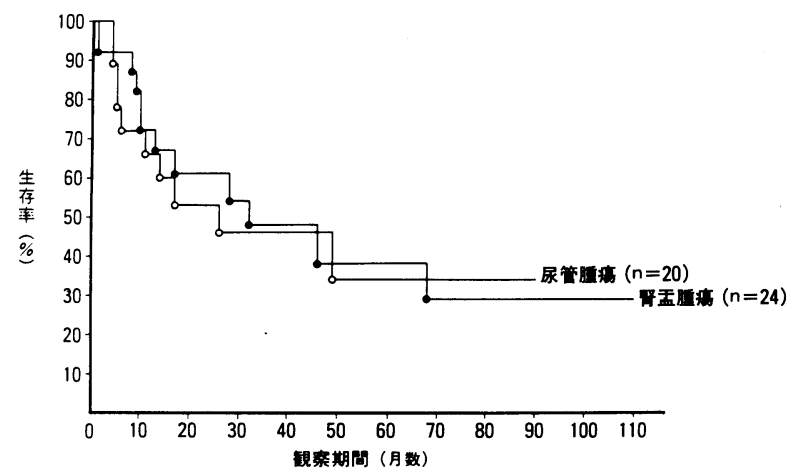

存率は $100 \%, 5$ 年生存率 $71 \%, \mathrm{~T} 3(\mathrm{n}=8)$ の 3 年生存 率 $46 \%, 5$ 年生存率 $46 \%, \mathrm{M}+(\mathrm{n}=15)$ の 3 年生存率 は $9 \%$ で，4年以上経過した例はみられなかった。 T1 と $\mathrm{M}+(\mathrm{p}<0.001), \mathrm{T} 3$ と $\mathrm{M}+(\mathrm{p}<0.05)$ の間に有意 差を認めた。

\section{d. 治療法別（図 5 ）}

腎孟尿管腫瘍に対する治療法別の症例の内訳は，腎 孟尿管膀脱全摘 1 例，腎尿管全摘（bladder cuff をつ ける）24例，腎尿管摘除（bladder cuff をつけない）

表 3 腎孟尿管腫瘍一治療法別の症例内訳

\begin{tabular}{l|r|r|r|c|c|c|c|c|c|c|c}
\hline & \multirow{2}{*}{} & \multirow{2}{*}{ 症例数 } & \multicolumn{5}{|c|}{ stage } & \multicolumn{4}{|c}{ grade } \\
\cline { 3 - 11 } & & $\mathrm{Tis}$ & $\mathrm{T} 1$ & $\mathrm{~T} 2$ & $\mathrm{~T} 3$ & $\mathrm{M}+$ & $\mathrm{TX}$ & $\mathrm{G} 1$ & $\mathrm{G} 2$ & $\mathrm{G} 3$ & $\mathrm{GX}$ \\
\hline 腎尿管膀胱全摘 & 1 & & & & 1 & & & & & 1 & \\
腎尿管全摘** & 24 & & 12 & 2 & 4 & 6 & & 1 & 15 & 8 & \\
腎尿管摘除** & 4 & & 1 & & 3 & & & & 3 & 1 \\
腎 摘 & 3 & & & & & 3 & & & 2 & 1 \\
尿管切除 & 1 & & & & & 1 & & & & 1 & \\
非手術 & 11 & 1 & & & & 5 & 5 & & 4 & 3 & 4 \\
\hline
\end{tabular}

*bladder cuff をつける

**bladder cuff をつけない 
表 4 腎孟腫瘍, 尿管腫瘍の症例内訳

\begin{tabular}{|c|c|c|c|c|c|c|c|c|c|c|c|}
\hline & \multirow{2}{*}{ 症例数 } & \multicolumn{6}{|c|}{ stage } & \multicolumn{4}{|c|}{ grade } \\
\hline & & Tis & $\mathrm{T} 1$ & $\mathrm{~T} 2$ & T3 & $\mathrm{M}+$ & $\mathrm{TX}$ & G1 & G2 & G3 & GX \\
\hline 腎孟腫瘍* & 24 & 1 & 7 & & 6 & 9 & 1 & 1 & 12 & 10 & 1 \\
\hline 尿管腫瘍 & 20 & & 6 & 2 & 2 & 6 & 4 & & 12 & 5 & 3 \\
\hline
\end{tabular}

*腎孟と尿管に発生した腫瘍は腎孟腫痬とする

4 例，腎摘 3 例，尿管切除 1 例，非手術 3 例であった。 腎摘，尿管切除，非手術といった非根治的治療は転移 を有する例が対象となった（表 3 ). 根治的治療群 $(n=$ 24）と非根治的治療群（n=20）に分けて生存率をみる 之, 根治的治療群の 3 年生存率 $83 \%, 5$ 年生存率 $63 \%$, 非根治的治療群の 3 年生存率 $7 \%, 5$ 年生存率 $7 \%$ で あった。両群間に有意差を認めた $(\mathrm{p}<0.001)$.

e. 剖位別（図 6 ）

移行上皮癌44例を部位別に腎血腫瘍と尿管腫瘍に分 けた，腎孟と尿管両方に腫瘍が存在するときは腎血腫 瘍に含めた，腎責腫瘍 $(\mathrm{n}=24)$ ，尿管腫瘍 $(\mathrm{n}=20)$ で 深達度, 異型度の背景因子に差はみられなかった（表 4 ). 腎孟腫瘍の 3 年生存率 $48 \%, 5$ 年生存率 $38 \%$, 尿 管腫瘍の 3 年生存率 $46 \%, 5$ 年生存率 $34 \%$ であった。 両群間に有意差はみられなかった。

\section{考察}

腎孟尿管腫瘍は膀胼腫瘍と比較して予後不良な疾患 である.予後に影響すると考えられる異型度, 深達度, 治療法について生存率を検討した。腎血尿管腫瘍全体 の 5 年生存率は $37 \%$, 腎盂腫瘍の 5 年生存率は $38 \%$, 尿管腫瑒の 5 年生存率は $34 \%$ であった。諸家の報告

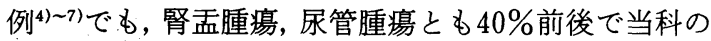
成績と差はみられなかった。

異型度別にみると， 5 年生存率は，G2 43\%, G3 42\% と差はみられなかった。報告例には， high grade と low gradeで有意な差がみられるといらものが多 (4) 8).これは $\mathrm{G} 1$ と $\mathrm{G} 2, \mathrm{G} 3$ との有意差で, $\mathrm{G} 2$ と $\mathrm{G} 3$ の 間には有意は差はないと考光られる。

深達度別にみると， 5 年生存率は，T1 71\%, T3 $46 \%, M+て ゙ 5$ 年経過した例はみられなかった。 $M+$ は T1，T3と比較して有意に生存率が低下した。 T1 T3の間には有意差はみられなかったが，T3で生存率 の低下する傾向がみられ，他の報告例でも深達度が進 行するにつれて生存率が低下した ${ }^{5) 6) 8)}$.

治療法別生存率は，5 年生存率で根治的治療群 $63 \%$, 非根治的治療群 $7 \%$ であった。背景因子として異型度 は両群間に差はなかったが, 深達度は根治的治療群で
深達度の低い例，非根治的治療群で深達度の高い例が 多くみられた。早期診断による根治的治療の必要性が 再認識された。

\section{結 語}

浜松医大泌尿器科開設後 10 年間で腎孟尿管腫瘍 46 例 を経験した。

1）性別は $3 ： 1$ と男に多く, 年齢は70歳代, 50 歳代 の順であった。

2）組織型では移行上皮癌 44 例，扁平上皮癌 2 例で あった。

3）深達度別では Tis 1 例， T2 2 例， T1 13例， T3 8 例, $\mathrm{M}+15$ 例, 異型度別では G1 1 例, G2 24例, G3 15例であった。

4） 5 年生存率は，移行上皮癌全体で $37 \%$, 部位別で は，腎孟腫瘍38\%，尿管腫瘍34\%，異型度別では， G2 43\%，G3 42\%，深達度別では，T1 71\%，T3 46\%， $\mathrm{M}+$ には 5 年以上の経過例はなかった。深達度による 有意差を認めた。

5）根治的治療群の 5 年生存率は $63 \%$, 非根治的治療 群の 5 年生存率は $7 \%$ \%った。

本論文の要旨は, 著者の一人牛山知已が第25回日本癌治 療学会総会で発表した。

\section{文献}

1) 日本泌尿器科学会, 日本病理学会編：泌尿器科・病 理, 膀胼癌取り扱い規約. 第 1 版. 金原出版, 東京, 1980.

2) Akaza, H., Koiso, K. and Niijima, T.: Clinical evaluation of urothelial tumor of the renal pelvis and ureter based on a new classification system. Cancer, 59, 1369-1375, 1987.

3）富永祐民：治療効果の判定のための実用統計学 一生命表の解説一。蟹書房, 東京, 1980 .

4）高安久雄, 小川秋実, 上野 精, 岸 洋一, 東原英 二：腎衁尿管腫瘍の治療成績。日泌尿会誌，69， 417-425, 1978.

5）川村寿一, 荒川陽一, 田中陽一, 東 義人, 岡田裕 作, 岡部達士郎, 宮川美栄子, 吉田 修：最近25年 間に経験した腎孟腫瘍. 泌尿紀要，27，905-916， 1981. 
6）平松 㑆, 伊集院真澄, 平尾佳彦, 小原荘一, 塩見 努, 馬場谷勝廣, 肱岡 隆, 橋本雅善, 丸山良夫, 末盛 毅, 岡村 清, 金子佳照, 堀井康弘, 守屋 昭, 岡島英五郎：上部尿路上皮性腫場の臨床的観 察。第 2 編。原発性尿管腫瘍. 泌尿紀要, 29, 1205-1217, 1983.

7) 多田安温, 中野悦次, 藤岡秀樹, 松田 稔, 高羽
津, 園田孝夫, 長船匡男：腎昷尿管腫毫102例の臨 床的検討. 日泌尿会誌，77，507-516，1986。

8) Cummings, K.B., Correa, R.J. Jr., Gibbons, R.P. Stoll, H.M., Wheelis, R.F. and Mason, J.T.: Renal pelvic tumors. J. Urol., 113, 158-162, 1975.

（1988年 9 月 13 日受理） 